\title{
PENERAPAN SANKSI PIDANA DALAM PENCEMARAN LINGKUNGAN HIDUP DITINJAU DARI UNDANG-UNDANG PERLINDUNGAN DAN PENGELOLAAN LINGKUNGAN HIDUP STUDI KASUS (PT.MARIMAS SEMARANG)
}

\author{
Oleh \\ Alif Candra Pratama, Rochmani
}

\begin{abstract}
ABSTRAK
Pencemaran lingkungan hidup tidak hanya berdampak buruk bagi kehidupan masyarakat yang ada sekarang namun juga akan mengancam kelangsungan hidupnya kelak. Adanya pencemaran lingkungan yang ditimbulkan dari adanya pembuangan limbah ke sungai yang berulang membuat perlunya ada penegakan sanksi pidana yang didasarkan pada UUPPLH. Kasus yang diangkat dalam penelitian ini adalah kasus pencemaran air di sungai Klampisan oleh PT. Marimas pada tahun 2013 yang berdampak pada warga di sekitar sungai Klampisan.

Penelitian ini bertujuan untuk menjelaskan penegakan sanksi pidana dalam pencemaran lingkungan hidup ditinjau dari UUPPLH dan menjelaskan hambatan dalam penegakan sanksi pidana dalam pencemaran lingkungan hidup ditinjau dari UUPPLH.

Penelitian ini menggunakan metode pendekatan yuridis normatif. Spesifikasi penelitian ini adalah deskriptif analitis yaitu menggambarkan peraturan perundang - undangan yang berlaku dikaitkan dengan teori - teori hukum dan praktek pelaksanaan hukum yang menyangkut permasalahan tersebut. Metode analisis data menggunakan cara deskriptif kualitatif

PT. Marimas, Semarang belum dikenakan sanksi pidana atas pencemaran sungai Klampisan yang diakibatkan karena kurangnya alat bukti dalam pembuktian pencemaran lingkungan sehingga penegakan sanksi pidana dalam pencemaran lingkungan hidup ditinjau dari UUPPLH di PT. Marimas, Semarang belum berjalan. Hambatan dalam penegakan sanksi pidana dalam pencemaran lingkungan hidup ditinjau dari UUPPLH di PT. Marimas, Semarang adalah kurangnya sosialiasi kepada masyarakat terkait hukum lingkungan, kendala dalam pembuktian karena di sepanjang Kali Klampisan terdapat sekitar 7 industri yang punya andil membuang limbah ke badan sungai tersebut dan pembangunan instalasi Pengelolaan Air Minum (PAM) di wilayah Purwoyoso, dan belum maksimalnya infrastruktur penegakan hukum yang disebabkan oleh kurangnya ketegasan dalam pelaksanaan peraturan perundangan dan sumber daya manusia di
\end{abstract}


Dinas Lingkungan Hidup yang jumlahnya belum memadai untuk melakukan pengawasan.

Kata Kunci : pencemaran, lingkungan hidup, sanksi pidana.

\section{PENDAHULUAN}

Lingkungan hidup adalah kesatuan ruang dengan semua benda, daya, keadaan, dan makhluk hidup termasuk manusia dan perilakunya yang telah mempengaruhi kesejahteraan manusia serta makhluk hidup lainnya. Pasal 33 ayat (3) UUD 1945 yang menegaskan bahwa bumi dan air serta kekayaan alam yang terkandung di dalamnya dikuasai oleh negara dan digunakan sebesarbesarnya kemakmuran rakyat. Dalam konteks ini ruang harus dilindungi dan dikelola secara terkoordinasi, terpadu, dan berkelanjutan.

Sesuai Pasal 1 UU No. 32 Tahun 2009 tentang Perlindungan dan Pengelolaan Lingkungan Hidup: 1. Lingkungan hidup adalah kesatuan ruang dengan semua benda, daya, keadaan, dan makhluk hidup, termasuk manusia dan perilakunya, yang mempengaruhi alam itu sendiri, kelangsungan perikehidupan, dan kesejahteraan manusia serta makhluk hidup lain. Secara substansi hal ini berbicara mengenai ruang wilayah atau daerah tidak bisa terlepas dari lingkungan hidup, karena lingkungan hidup adalah kesatuan ruang dengan semua benda, daya keadaan dan makhluk hidup, termasuk manusia dan perilakunya.

Walaupun hak untuk hidup dan mendapatkan lingkungan yang baik dan sehat dapat berdiri sendiri, namun adakalanya hak tersebut sangat berkaitan erat dengan norma konstitusi lainnya yang bersinggungan dengan lingkungan, yaitu norma "pembangunan berkelanjutan” dan "berwawasan lingkungan”.

Pembangunan berkelanjutan (sustainable development) merupakan standar yang tidak hanya ditujukan bagi perlindungan lingkungan, melainkan juga bagi kebijaksanaan pembangunan, artinya: ${ }^{1}$ Dalam penyediaan, penggunaan, peningkatan kemampuan sumber daya alam dan peningkatan taraf ekonomi, perlu menyadari pentingnya pelestarian fungsi lingkungan hidup, kesamaan derajat antar generasi, kesadaran terhadap hak dan kewajiban masyarakat, pencegahan terhadap pembangunan yang desktruktif (merusak) yang tidak bertanggung jawab terhadap lingkungan, serta berkewajiban untuk

1 Alvi Syahrin, 1999, Pembangunan Berkelanjutan (Perkembangannya, PrinsipPrinsip dan Status Hukumnya), Fakultas Hukum USU, Medan, hal. 27 
turut serta dalam melaksanakan pembangunan berkelanjutan pada setiap lapisan masyarakat.

Lingkungan hidup dalam pengertian ekosistem tidak mengenal batas wilayah, baik wilayah negara (nasional) maupun wilayah administratif dan daerah Provinsi, Kabupaten maupun Kota yang bersifat otonomi. Dalam penataan ruang daerah secara otonomi tetap tidak boleh mengabaikan adanya prinsip-prinsip tersebut karena mengikat secara undang-undang. Manusia dan lingkungan pada hakekatnya adalah satu bangunan yang seharusnya saling menguatkan karena manusia amat bergantung pada lingkungan sedang lingkungan juga bergantung pada aktivitas manusia. Namun dilihat dari sisi manusia maka lingkungan adalah sesuatu yang pasif, sedang manusialah yang aktif, sehingga kualitas lingkungan amat bergantung pada kualitas manusia. ${ }^{2}$

Kesadaran akan pengelolaan lingkungan hidup bagi kelestarian lingkungan hidup di Indonesia baru terlihat secara nyata pada tanggal 25 Februari 1982 dengan adanya Rencana Undang-Undang Lingkungan Hidup disahkan, yaitu Undang-Undang Nomor 4 tahun 1982 tentang ketentuan-ketentuan pokok pengelolaan lingkungan hidup (Lembaran Negara RI Nomor 12)

2 Koesnadi Hardjasoemantri, 2006, Hukum Tata Lingkungan, Gadjah Mada University Press, Edisi ke-7, Cetakan ke-14, Yogyakarta, hal 18-19 selanjutnya disingkat dengan UULH. Pada tanggal 19 September 1997 UULH dicabut dan diganti dengan Undang-Undang Nomor 23 Tahun 1997 (Lembaran Negara tahun 1997 Nomor 68 dan tambahan lembaran Negara No 3699) tentang Pengelolaan Lingkungan Hidup (selanjutnya disingkat dengan UUPPLH) dengan alasan antara lain UULH perlu disempurnakan. Pada tahun 2009 bulan Oktober lahirlah UndangUndang Nomor 32 Tahun 2009 tentang Perlindungan dan Pengelolaan Lingkungan Hidup (selanjutnya disingkat dengan UUPPLH) dengan tambahan lembaran Negara Republik Indonesia Nomor 5059. Adanya pergantian UUPPLH dengan UUPPLH, secara filosofis UUPPLH memandang dan menghargai bahwa arti penting akan hak-hak asasi berupa hak atas lingkungan hidup yang baik dan sehat bagi warga negara. ${ }^{3}$ Indonesia, pertama kali hak atas lingkungan yang sehat dan baik diakui dalam sebuah UULH yang diganti dengan UUPPLH. Kemudian juga hak atas lingkungan hidup yang sehat dan baik di Indonesia diakui sebagai HAM melalui ketetapan MPR RI Nomor XVII/MPR/1998 tentang Hak Asasi Manusia. Di salah satu pasal pada Deklarasi Nasional tentang HAM menetapkan bahwa,"setiap orang berhak atas lingkungan hidup yang sehat dan baik. UUPPLH, juga memasukkan landasan filosofi tentang konsep pembangunan berkelanjutan

${ }^{3}$ Ibid, hal 21 
dan berwawasan lingkungan dalam rangka pembangunan ekonomi. Ini penting dalam pembangunan ekonomi nasional karena persoalan lingkungan ke depan semakin kompleks dan syarat dengan kepentingan investasi. Persoalan lingkungan adalah persoalan kita semua, baik pemerintah, dunia investasi maupun masyarakat pada umumnya. ${ }^{4}$

\section{METODE PENELITIAN}

\section{Tipe Penelitian}

Metode yang digunakan oleh penulis dalam penelitian ini adalah tipe penelitian yuridis normatif. Pengertian yuridis dimaksudkan di dalam meninjau dan melihat serta menganalisis masalah digunakan prinsip-prinsip dan asas-asas hukum, sedangkan normatif berarti bahwa di dalam melakukan penelitian menekankan pada langkah-langkah spekulatif-teoritis (langkah secara teori) dan analisis normatif-kualitatif. ${ }^{5}$ Penelitian yuridis normatif merupakan penelitian kepustakaan yaitu penelitian terhadap data sekunder.

\section{Metode Penyajian Data}

Metode penyajian data dalam penelitian ini dilakukan dengan cara deskriptif analitis yaitu menjelaskan atau menggambarkan kenyataankenyataan yang terjadi pada objek

${ }^{4}$ Ibid, hal 22

5 Soerjono Soekanto, 1986, Pengantar Penelitian Hukum. Universitas Indonesia. Jakarta, Hal. 10. penelitian secara tepat dan jelas untuk memperoleh kejelasan tentang masalah yang timbul. Dalam penelitian ini menjelaskan, kemudian data tersebut disajikan dalam bentuk uraian keterangan mengenai tindak pidana pencemaran lingkungan.

\section{Jenis dan Sumber Data Penelitian}

1. Jenis Data

Jenis data yang digunakan dalam penelitian ini adalah data sekunder. Data sekunder merupakan keterangan atau fakta - fakta yang diperoleh secara tidak langsung, tetapi melalui studi kepustakaan melalui literatur - literatur, pendapat para ahli serta perundang - undangan yang berkaitan dengan penelitian yang dilakukan.

2. Sumber Data

Sumber data yang dipergunakan dalam penelitian ini adalah sumber Data Sekunder yang merupakan sumber data yang berasal dari arsip - arsip, dokumen, perundang - undangan yang berfungsi sebagai pendukung dari data primer.

Data sekunder dalam penelitian ini dikelompokkan menjadi 3 (tiga), yaitu

1. Bahan Hukum Primer, yaitu bahan yang mengikat, terdiri dari :

a. Undang-Undang Dasar Negara Kesatuan Republik Indonesia 1945 
b. Undang-undang Republik Indonesia No. 32 Tahun 2009 tentang Perlindungan dan Pengelolaan Lingkungan Hidup

c. Undang-Undang Nomor 3 Tahun 2014 tentang Perindustrian

d. Peraturan Pemerintah Republik Indonesia Nomor 27 Tahun 2012 tentang Izin Lingkungan

e. Peraturan Menteri Negara Lingkungan Hidup Republik Indonesia Nomor 5 Tahun 2012 tentang Jenis Rencana Usaha dan/atau Kegiatan yang Wajib Memiliki Analisis Mengenai Dampak

Lingkungan Hidup

f. Peraturan Menteri Negara Lingkungan Hidup Republik Indonesia Nomor 17 Tahun 2012 tentang Pedoman Keterlibatan Masyarakat dalam proses Analisis Dampak Lingkungan Hidup dan Izin Lingkungan

g. Peraturan Menteri Negara Lingkungan Hidup Republik Indonesia Nomor 8 Tahun 2013 tentang Tata Laksana Penilaian dan Pemeriksaan Dokumen Lingkungan Hidup serta Penerbitan izin Lingkungan h. Peraturan Menteri Negara Lingkungan Hidup Republik Indonesia Nomor 7 Tahun 2014 tentang Kerugian Lingkungan Hidup akibat Pencemaran dan/atau Kerusakan Lingkungan Hidup

i. Peraturan perundangan lainnya yang berkaitan dengan materi penulisan hukum ini

2. Bahan Hukum Sekunder, yaitu bahan yang memberi penjelasan bagi bahan hukum primer, terdiri dari :

a. Buku-buku atau hasil penelitian yang membahas tentang lingkungan hidup.

b. Majalah - majalah dan dokumen - dokumen yang berkaitan dengan masalah lingkungan hidup.

3. Bahan Hukum Tersier, yaitu bahan hukum yang memberikan petunjuk dan penjelasan terhadap bahan hukum primer dan sekunder, terdiri dari : Kamus hukum, Kamus besar Bahasa Indonesia.

\section{Metode Analisis Data}

Metode analisis data menggunakan cara deskriptif kualitatif dengan memberikan gambaran secara khusus berdasarkan data yang dikumpulkan secara sistematis. Data yang diperoleh akan dianalisis secara analisis deskriptif 
kualitatif, yaitu data yang diperoleh, dipilih dan disusun secara sistematis. Secara kualitatif untuk mencapai kejelasan masalah yang akan dibahas, selanjutnya tahap penemuan hasil yang diperoleh dari wawancara dan penelitian kepustakaan yaitu dengan mempelajari buku-buku atau literaturliteratur yang relevan dengan pokok permasalahan dan dari penelitian lapangan, sehingga didapat suatu kesimpulan, kemudian disusun secara sistematis dalam bentuk laporan penelitian atau skripsi.

Penerapan sanksi pidana dalam pencemaran lingkungan hidup akan dianalisis sesuai dengan Pasal 98-115 UUPPLH Bab XV tentang ketentuan pidana dalam pencemaran lingkungan hidup.

\section{HASIL PENELITIAN DAN ANALISIS DATA}

\section{Posisi Kasus Pencemaran Lingkungan Hidup oleh PT. Marimas}

Limbah pabrik PT. Marimas yang dibuang ke sungai jelas merupakan salah satu bentuk pencemaran lingkungan hidup, apalagi dalam kasus tersebut pipa saluran pembuangan limbah ke sungai bocor dan menyebabkan sumur warga sekitar pabrik tercemar dan air tidak dapat digunakan. Oleh karena itu perlu adanya penegakkan hukum terhadap pencemaran yang dilakukan oleh PT. Marimas tersebut agar terciptanya keadilan, kemanfaatan, dan kepastian hukum.

Berdasarkan data dari Dinas Lingkungan Hidup

Penegakan Sanksi Pidana Dalam Pencemaran Lingkungan Hidup Ditinjau dari UUPPLH (Studi di PT. Marimas, Semarang)

Penegakan hukum mempunyai makna, bagaimana hukum itu harus dilaksanakan, sehingga dalam penegakan hukum tersebut harus diperhatikan unsur-unsur kepastian hukum. Hal ini dimaksudkan agar tercipta ketertiban dalam masyarakat. Sebaliknya masyarakat menghendaki adanya manfaat dalam pelaksanaan peraturan atau penegakan hukum lingkungan tersebut. Hukum lingkungan dibuat dengan tujuan untuk melindungi lingkungan dan memberi manfaat kepada masyarakat. Artinya peraturan tersebut dibuat adalah untuk kepentingan masyarakat, sehingga jangan sampai terjadi bahwa, karena dilaksanakannya peraturan tersebut, masyarakat justru menjadi resah. Dalam penegakan hukum, lingkungan harus diperhatikan, namun demikian hukum tidak identik dengan keadilan, karena hukum itu sifatnya umum, mengikat semua orang, dan menyamaratakan. Dalam penataan dan penegakan hukum lingkungan, unsur kepastian, unsur kemanfaatan ,dan unsur keadilan harus dikompromikan, ketiganya harus mendapat perhatian secara proporsional. Sehingga 
lingkungan yang tercemar dapat control (pengecekan) juga dipulihkan kembali.

Air merupakan salah satu bentuk lingkungan hidup fisik, dimana jika air ini tercemar maka akan berdampak besar bagi kelangsungan hidup makhluk hidup. Limbah pabrik PT. Marimas yang dibuang ke sungai jelas merupakan salah satu bentuk pencemaran lingkungan hidup, apalagi dalam kasus tersebut pipa saluran pembuangan limbah ke sungai bocor dan menyebabkan sumur warga sekitar pabrik tercemar dan air tidak dapat digunakan. Oleh karena itu perlu adanya penegakkan hukum terhadap pencemaran yang dilakukan oleh PT. Marimas tersebut agar terciptanya keadilan, kemanfaatan, dan kepastian hukum.

Penegakan hukum lingkungan berkaitan erat dengan kemampuan aparatur dan kepatuhan warga masyarakat terhadap peraturan yang berlaku, yang meliputi tiga bidang hukum, yaitu administratif, pidana, dan perdata. PT Marimas yang melakukan tindak pidana atau pelanggaran, yaitu pencemaran, dimana pencemaran yang dilakukan oleh korporasi ini ialah limbah yang dibuang sembarangan melalui saluran pembuangan melalui pipa saluran dimana pipa saluran ini mengalami kebocoran, sehingga menyebabkan pembuangan limbah ke aliran sungai, meski terlihat tidak sengaja namun pengelolaan yang dilakukan oleh PT Marimas terlihat tidak baik, tidak ada pengawasan yang dilakukan oleh pihak manejemen maupun karyawan dari PT ini, jika pengelolaanya baik, kebocoran yang ada akan segera dapat ditanggulangi, ditangani dimana tidak akan menyebabkannya pembuangan limbah ke aliran sungai yang ada tersebut. Dengan ini pertanggungjawaban korporasi haruslah diterapkan, sanksi - sanksi berupa sanksi administratif, sanksi pidana juga perdata dapat diberlakukan, sesuai dengan ketentuan undang-undang yang berlaku. Penerapan sanksi dapat dilakukan jika hasil uji baku mutu limbah terbukti di atas ketentuan yang telah ditetapkan ${ }^{6}$

Gugatan telah dilakukan oleh warga Kampung Klampisan, kelurahan Purwoyoso, Ngaliyan, Semarang, namun hingga tahun 2017 masih belum ada putusan mengenai pencemaran tersebut. Saat ini yang dilakukan oleh PT. Marimas adalah pemberian kompensasi kepada warga sekitar sungai Klampis dengan pendekatan personal dan tanpa melalui Dinas Lingkungan Hidup Kota Semarang, sementara secara pidana belum ada sanksi yang diberikan maupun belum ada kelanjutan kasus pidana tersebut. ${ }^{7}$

\footnotetext{
${ }^{6}$ Noramaning Istini, Wawancara, Kepala sub bidang Penanganan Sengketa Lingkungan DLH Kota Semarang, Semarang:Tanggal 8Agustus 2018

${ }^{7}$ Noramaning Istini, Wawancara, Kepala sub bidang Penanganan Sengketa Lingkungan
} 


\section{Hambatan Dalam Penegakan Sanksi Pidana Dalam Pencemaran Lingkungan Hidup Ditinjau dari UUPPLH (Studi di PT. Marimas, Semarang)}

Penegakan sanksi pidana dalam kasus pencemaran lingkungan hidup ditinjau dari UUPPLH pada studi kasus di PT. Marimas Semarang mengalami hambatan. Hal ini terbukti dari belum adanya kelanjutan dari hasil gugatan warga terhadap PT. Marimas, walaupun unsur pencemaran telah terbukti sehingga secara perdata, administrasi dan pidana, PT. Marimas dapat dikenakan sanksi. Hambatan yang terjadi tersebut berdasarkan wawancara dengan Dinas Lingkungan Hidup adalah sebagai berikut: $^{8}$

"Jelas, penegakan hukum lingkungan ini pun jauh lebih rumit dari pada delik lain, karena seperti telah dikemukakan sebelumnya hukum lingkungan menempati titik silang berbagai pendapat hukum klasik. Proses penegakan hukum administratif akan lain dari pada proses penegakan hukum perdata maupuan hukum pidana. Gugatan lebih panjang, proses panjang, biaya juga meningkat, ada kalanya masyarakat tidak mampu

DLH Kota Semarang, Semarang:Tanggal 8Agustus 2018

${ }^{8}$ Noramaning Istini, Wawancara, Kepala sub bidang Penanganan Sengketa Lingkungan DLH Kota Semarang, Semarang:Tanggal 8Agustus 2018 menanggungnya, karena ada kemungkinan kalah. Sanksi juga tumpang tindih, dan pada akhirnya masyarakat juga butuhnya diganti rugi”.

Pada umumnya masalah dimulai pada satu titik, yaitu terjadinya pelanggaran hukum lingkungan. Dari titik perangkat ini dapat dimulai dari orang pribadi anggota masyarakat, korban penegak hukum yang mengetahui langsung terjadinya pelanggaran tanpa adanya laporan atau pengaduan. Tujuan tempat pelapor kepada Bapedal LSM atau organisasi lingkungan hidup jika ingin memilih jalan perdata terutama tuntutan perbuatan melanggar hukum dapat melakukan gugatan sendiri kepada hakim perdata atas nama masyarakat (algemen belang, maatschappelijk belang). Jika mereka kurang mampu memikul biaya perkara, berdasarkan Pasal 25 Keppres Nomor 55 tahun 1991, dapat meneruskan kepada jaksa yang akan menggugat perdata atas nama kepentingan umum atau kepentingan masyarakat. Di kejaksaan terdapat bidang khusus untuk ini, yaitu Jaksa Agung Muda Perdata dan Tata Usaha Negara.

Disamping itu, jika anggota masyarakat, korban, LSM, organisasi lingkungan hidup, bahkan siapa saja dapat membuat laporan pidana kepada polisi. Siapa pun juga mengetahui terjadinya kejahatan wajib melapor kepada penyidik. Dari kepolisian 
dapat diminta petunjuk jaksa secara teknis yuridis. Jalur ini jelas hukum pidana, akan tetapi, jaksa masih dapat menyelesaikan berdasarkan azas oportunitas, baik dengan syarat maupun tanpa syarat. Jika semua jalur akan ditempuh berhubung pelanggaran telah demikian serius dan menyinggung semua dimensi, misalnya melanggar syarat-syarat suatu izin menimbulkan kerugian finansial kepada orang atau masyarakat, lagi pula ia seorang residiv bahkan telah menimbulkan korban luka atau mati, penegak hukum dan yang berkepentingan melakukan tugasnya. Agar sanksi yang dijatuhkan tidak tumpang tindih misalnya denda (berdasarkan sanksi administratif dan pidana) maka penegak hukum perlu bermusyawarah sehingga tindakan yang dilakukan masing-masing terkoordinasi dengan baik.

Kendala lain yang dialami oleh penyidik dan Dinas Lingkungan Hidup adalah permasalahan pembuktian terjadinya kerusakan lingkungan hidup. ${ }^{9}$

"Saat ini ada 7 industri di sepanjang Klampisan, susah untuk membuktikan yang mana yang membuang limbah ini, walau indikasi sangat jelas mengarah pada PT. Marimas, namun jika dibuat bukti di

${ }^{9}$ Noramaning Istini, Wawancara, Kepala sub bidang Penanganan Sengketa Lingkungan DLH Kota Semarang, Semarang:Tanggal 8Agustus 2018 persidangan, maka ini lemah. Belum lagi sedang adanya pembangunan instalasi PAM di Purwoyoso dari Bank Air, ini juga jadi argument bagi mereka. Gugatan juga dianggap kurang lengkap kalau begini.”

Masalah pencemaran ini jika tidak ditanggulangi akan mengancam kelestarian fungsi lingkungan hidup. Di sepanjang Kali Klampisan terdapat sekitar 7 industri yang punya andil membuang limbah ke badan sungai tersebut. Permasalahan ini menjadi semakin mendapat perhatian dengan dibangunnya instalasi Pengelolaan Air Minum (PAM) di wilayah Purwoyoso yang merupakan proyek peningkatan kapasitas pengelolaan air minum untuk mencukupi kebutuhan air minum di daerah Ngaliyan atas bantuan Bank Dunia. Untuk dapat membuktikan bahwa suatu perbuatan telah menimbulkan pencemaran perlu penyidikan, penyidikan ini dilakukan oleh aparat Polri dan Dinas Lingkungan Hidup. Polisi (penyidik) dalam penyidikan berkesimpulan bahwa telah terjadi pencemaran karena kesengajaan, sehingga perkara ini diajukan ke Pengadilan Negeri Semarang, namun gugatan saat ini masih belum diproses karena dianggap kurang lengkap. Perbedaan ini menunjukkan bahwa permasalahan lingkungan hidup merupakan permasalahan kompleks, rumit dalam segi pembuktian dan penerapan pasal, 
serta subyektifitas pengambil keputusan cukup tinggi, sehingga perlu suatu media untuk menyederhanakan, memudahkan dan meminimisasi unsur subyektifitas.

Hambatan lain yang dialami adalah kurang maksimalnya fungsi pengawasan akan pencemaran lingkungan dalam hal ini adalah pembuangan limbah karena kurangnya personil baik dari DLH maupun aparat hukum lainnya. ${ }^{10}$

Negara harusnya memiliki power untuk mencabut izin operasi atau konsesi atas perusahaan yang melakukan pencemaran sungai. Hanya ada dua kemungkinan jika terjadi pencemaran limbah di tempat yang sama dengan jumlah kadar limbah mengalami peningkatan, yaitu mereka sengaja melakukan pencemaran tersebut. Jika ada kekuasaan pemerintah seperti itu, maka dapat dipastikan angka pencemaran limbah akan turus secara drastis. Untuk itu diperlukan suatu aturan hukum berupa Peraturan Pemerintah atau Perpu, karena aturan hukum yang ada saat ini belumlah memadai. Selain itu, kurangnya sumber daya manusia dari Dinas Lingkungan Hidup juga membuat pengawasan yang dilakukan oleh Dinas Lingkungan Hidup tidak dapat berjalan dengan maksimal.

10 Noramaning Istini, Wawancara, Kepala sub bidang Penanganan Sengketa Lingkungan DLH Kota Semarang, Semarang:Tanggal 8Agustus 2018

\section{SIMPULAN DAN SARAN}

\section{Simpulan}

Berdasarkan hasil penelitian yang telah dilakukan, maka dapat diambil kesimpulan dari hasil penelitian tersebut sebagai berikut :

1. Berdasarkan hasil pengujian limbah cair PT. Marimas yang dilakukan pada tahun 2013, didapatkan hasil analisa dan laporan pengujian limbah tersebut diperoleh kesimpulan bahwa kadar maksimum untuk parameter TSS, BOD dan COD limbah cair PT Marimas pada tahun 2013 telah melebihi baku mutu limbah cair yang ditentukan.

Dampak pencemaran air sungai Klampisan ini adalah sekitar 31 warga yang mengalami sakit kulit ketika menggunakan air sungai untuk mandi dan cuci muka, 18 orang warga mengalami keracunan dan dilarikan ke rumah sakit setelah meminum air sungai yang telah direbus dan lebih dari 20 orang warga mengalami gangguan pencernaan lainnya karena menggunakan air sungai untuk memasak.

Hasil pengujian limbah pada kasus meluapnya saluran pembuangan limbah menunjukkan bahwa tidak adanya upaya perbaikan fasilitas pengolahan limbah dari PT. Marimas. Hal ini terbukti dari meningkatnya nilai semua 
indikator limbah cair dari tahun 2013 ke tahun 2014.

2. PT. Marimas, Semarang belum dikenakan sanksi pidana atas pencemaran sungai Klampisan yang diakibatkan karena kurangnya alat bukti dalam pembuktian pencemaran lingkungan sehingga penegakan sanksi pidana dalam pencemaran lingkungan hidup ditinjau dari UUPPLH di PT. Marimas, Semarang belum berjalan. Berdasarkan hasil penelitian, PT. Marimas telah memenuhi unsur melepaskan atau membuang zat, energy dan atau komponen lain yang berbahaya atau beracun masuk di atas tanah atau ke dalam tanah berbahaya atau beracun masuk di atas atau ke dalam tanah, serta tidak melakukan pengelolaan limbah B3 secara tepat. Namun belum ada sanksi pidana yang diberikan kepada PT. Marimas.

3. Hambatan dalam penegakan sanksi pidana dalam pencemaran lingkungan hidup ditinjau dari UUPPLH di PT. Marimas, Semarang adalah sebagai berikut:

a. Hambatan substansi

Kurangnya sosialiasi kepada masyarakat terkait hukum lingkungan, kendala dalam pembuktian karena di sepanjang Kali Klampisan terdapat sekitar 7 industri yang punya andil membuang limbah ke badan sungai tersebut dan pembangunan instalasi Pengelolaan Air Minum (PAM) di wilayah Purwoyoso

b. Hambatan struktural

Belum maksimalnya infrastruktur penegakan hukum yang disebabkan oleh kurangnya ketegasan dalam pelaksanaan peraturan perundangan dan sumber daya manusia di Dinas Lingkungan Hidup yang jumlahnya belum memadai untuk melakukan pengawasan.

\subsection{Saran}

Berdasarkan hasil penelitian, dapat diberikan saran yang dapat digunakan sebagai bahan pertimbangan dan masukan sebagai berikut :

\section{Bagi pemerintah}

a. Pemerintah sebaiknya perlu merumuskan suatu Peraturan Pemerintah untuk mencabut izin operasi atau konsesi atas perusahaan yang melakukan pencemaran sungai untuk memberikan efek jera pada perusahaan dan memberikan contoh bagi perusahaan lain agar tidak melakukan pencemaran lingkungan khususnya sungai.

b. Pemerintah juga sebaiknya dapat menambah personil 
atau karyawan Dinas

Lingkungan Hidup yang saat ini masih dianggap kurang memadai untuk melakukan pengawasan.

2. Bagi Dinas Lingkungan Hidup Kota Semarang

Peraturan yang baik dalam pengeolaan lingkungan, seharusnya dapat diimbangi peran lembaga pemerintah serta peran masyarakat yang baik pula. Koordinasi antar instansi pemerintah yang bersangkutan serta peran pemerintah yang bertugas mengawasi dan menegakkan jalannya hukum lingkungan harus terjalin dengan baik. Koordinasi antara BLH dengan satpol PP, dengan dinas perijinan terpadu dan instansi lain yang terkait penegakkan hukum lingkungan harus menguatkan koordinasi dan kerjasama antar lembaga. Efektifitas suatu peraturan akan berjalan apabila ada keserasian antara penegak hukum dan masyarakat yang baik.

\section{DAFTAR PUSTAKA}

\section{Buku}

Ali, Mahrus, 2011, Dasar-dasar Hukum Pidana, Jakarta: Sinar Grafika.

Cahyono, 2010, "Penerapan Sanksi Pidana Dalam Kasus Pencemaran Lingkungan Hidup”, Varia Peradilan
Majalah Hukum Tahun XXV No. 294.

Erwin, Muhamad, 2011, Hukum Lingkungan Dalam Sistem Kebijaksanaan Pembangunan Lingkungan Hidup, Refika Aditama, Bandung.

Hamzah, Andi, 2005, Pemberantasan

Korupsi Melalui Hukum Nasional dan Internasional, Jakarta: Raja Grafindo Persada.

Hardjasoemantri, Koesnadi, 2006,

Hukum Tata Lingkungan, Gadjah Mada University Press, Edisi ke-7, Cetakan ke14, Yogyakarta.

Helmi, 2012, Hukum Perizinan Lingkungan Hidup, Sinar Grafika, Jakarta.

KUHP dan KUHAP, Surabaya: Kesindo Utama, 2012.

Mulyadi, Lilik, 2007, Putusan Hakim dalam Hukum Acara Pidana Teori, Praktik, Teknik Penyusunan, dan Permasalahannya, PT. Citra Aditya Bakti Bandung.

Rahmadi, Takdir, 2003, Hukum Pengelolaan Bahan Berbahaya dan Beracun, Airlangga University Press

Riyanto, 2013, Limbah Bahan Berbahaya dan Beracun (Limbah B3), CV Budi Utama,Yogyakarta.

Rochmani, 2014, Hukum Lingkungan Dan Penegakan Hukum, Pustaka Magister, Semarang. 
Suparni, Niniek, 2007, Eksistensi Pidana Denda dalam Sistem Pidana dan Pemidanaan, Jakarta: Sinar Grafika.

Waluyo, Bambang, 2004, Pidana dan Pemidanaan, Jakarta: Sinar Grafika.

$\begin{array}{cr}\text { Wardhana, Wisnu } & \text { Arya, 2004, } \\ \text { Dampak } & \text { Pencemaran } \\ \text { Lingkungan, } & \text { Andi, } \\ \text { Yogyakarta. } & \end{array}$

\section{Peraturan Perundangan}

Undang-Undang Dasar Negara

Kesatuan Republik Indonesia 1945

Undang-Undang Republik Indonesia Nomor 23 Tahun 1997 tentang Pengelolaan Lingkungan Hidup

Undang-undang Republik Indonesia

No. 32 Tahun 2009 tentang

Perlindungan dan Pengelolaan

Lingkungan Hidup

Undang-Undang Nomor 3 Tahun 2014 tentang Perindustrian

Peraturan Pemerintah Republik Indonesia Nomor 27 Tahun 2012 tentang Izin Lingkungan

Peraturan Menteri Negara Lingkungan Hidup Republik Indonesia Nomor 5 Tahun
2012 tentang Jenis Rencana Usaha dan/atau Kegiatan yang Wajib Memiliki Analisis Mengenai Dampak Lingkungan Hidup

Peraturan Menteri Negara Lingkungan Hidup Republik Indonesia Nomor 17 Tahun 2012 tentang Pedoman Keterlibatan Masyarakat dalam proses Analisis Dampak Lingkungan Hidup dan Izin Lingkungan

Peraturan Menteri Negara Lingkungan Hidup Republik Indonesia Nomor 8 Tahun 2013 tentang Tata Laksana Penilaian dan Pemeriksaan Dokumen Lingkungan Hidup serta Penerbitan izin Lingkungan

Peraturan Menteri Negara Lingkungan Hidup Republik Indonesia Nomor 7 Tahun 2014 tentang Kerugian Lingkungan Hidup akibat Pencemaran dan/atau Kerusakan Lingkungan Hidup

\section{$\underline{\text { Website }}$}

http://id.wikipedia.org/wiki/Pembang unan_berkelanjutan 